\title{
Comparative Evaluation of the Effect of Different Beverages on the Surface Roughness and Microhardness of Human Enamel Surface: An In Vitro Study
}

\author{
Tarannum Ghavri ${ }^{1}$, Anuradha Pathak ${ }^{2}$, Navroop K Bajwa ${ }^{3}$
}

\begin{abstract}
Milk-derived beverages are considered to be beneficial to not only health but also to dental tissue. However, the exact nature of the effect of these beverages should be studied to formulate an exact diet plan for a child so that only good effects can be obtained from a dietary derivative. Aim and objective: To evaluate and compare the surface roughness and microhardness of human enamel surface after exposure to different immersion regimes in milk-based beverages.

Materials and methods: A total of 90 samples were prepared from caries-free premolars extracted for orthodontic purposes. The samples were then randomly divided into three groups based on the immersion beverage used vis-a-vis chocolate milk, sweet lassi, and soy milk. The immersion cycles were done for 7 days. After the immersions were complete, the samples were dried and subjected to microhardness and surface roughness testing.

Results: The surface roughness of the exposed surface of enamel was found to be in the following order: sweet lassi (verka) > control > soya milk chocolate (sofit) > chocolate milk (Amul Kool Koko). The microhardness of the exposed surface of enamel was found to be in the following order: chocolate milk (Amul Kool Koko) > soya milk chocolate (sofit) $>$ sweet lassi (verka) $>$ control.

Keywords: Laboratory research, Microhardness, Surface roughness, $\mathrm{pH}$, Titratable acidity.

International Journal of Clinical Pediatric Dentistry (2021): 10.5005/jp-journals-10005-2011
\end{abstract}

\section{INTRODUCTION}

Urbanization and industrialization have led to a change in dietary habits. The children are being provided with a variety of options such as carbonated beverages, fruit-based beverages, milk and milk products, etc. This increase in the options is in turn responsible for increased consumption of these beverages especially as midmeal energy boosters. Milk and its products are considered to be important for children as it contains important nutrients for children's growth. They are well known for their ability to neutralize dietary acids. ${ }^{1}$ Thus, the popularity of milk-based beverages like lassi, yogurt, and soy milk has been increasing at a good pace in India since they are considered as "Health drinks".

Enamel, despite being the hardest structure of the human body is influenced by these beverages. ${ }^{2,3}$ The effects of a beverage on the enamel are influenced by several chemical parameters including $\mathrm{pH}$, titratable acidity, buffering capacity, calcium chelating properties, viscosity, and concentration of calcium, phosphate, and fluoride ions. ${ }^{4,5}$ Milk and milk products provide a supersaturated solution of calcium and phosphates to the enamel. However, the milk-based beverages available in the market like lassi and soya milk have an inherent low $\mathrm{pH}$ along with added preservatives which may complicate their interactions in the oral cavity. Hence, to assess the safety of these beverages it is indispensable to study the effect of these beverages on the mechanical properties of enamel. Surface roughness and microhardness are valuable parameters in the assessment of the interaction between various solutions and enamel. These parameters assess the effect of demineralization and remineralization of enamel over a period of time. ${ }^{6}$

Therefore, the present study was conducted in vitro with the aim to compare and evaluate the surface roughness and microhardness

\footnotetext{
${ }^{1-3}$ Department of Pedodontics and Preventive Dentistry, Government Dental College and Hospital, Patiala, Punjab, India

Corresponding Author:Tarannum Ghavri, Department of Pedodontics and Preventive Dentistry, Government Dental College and Hospital, Patiala, Punjab, India, Phone: +91 9996341999, e-mail: smartdoctanu@ gmail.com

How to cite this article: Ghavri T, Pathak A, Bajwa NK. Comparative Evaluation of the Effect of Different Beverages on the Surface Roughness and Microhardness of Human Enamel Surface: An In Vitro Study. Int J Clin Pediatr Dent 2021;14(5):657-661.

Source of support: Nil

Conflict of interest: None
}

of human enamel surface after exposure to different immersion regimes in milk and milk-based beverages.

\section{Materials and Methods}

The following materials were used for the study (Fig. 1):

- Premolars extracted for orthodontic reason

- Sterilized gloves

- Tweezer

- Straight handpiece

- 20-gauge needle

- Double-sided diamond disk

- Sterile, air-tight plastic containers

- 10-mL syringe

- Artificial saliva

- Distilled water

- Beverages (chocolate milk, sweet lassi, soya milk chocolate). 
A total of 90 samples were prepared from caries-free premolars extracted for orthodontic purposes. The teeth were cut at the cementoenamel junction using a double-sided diamond disk to obtain coronal portions. These coronal portions were embedded in the block of cold-cure acrylic resin with facial surfaces facing upward. The left half of the sample was covered with a layer of pink modeling wax so that this surface was prevented from any contact with the immersion beverage, hence making the tooth serve as its own control (Fig. 2). The samples were then randomly divided into three groups based on the immersion beverage used. The samples were grouped as:-
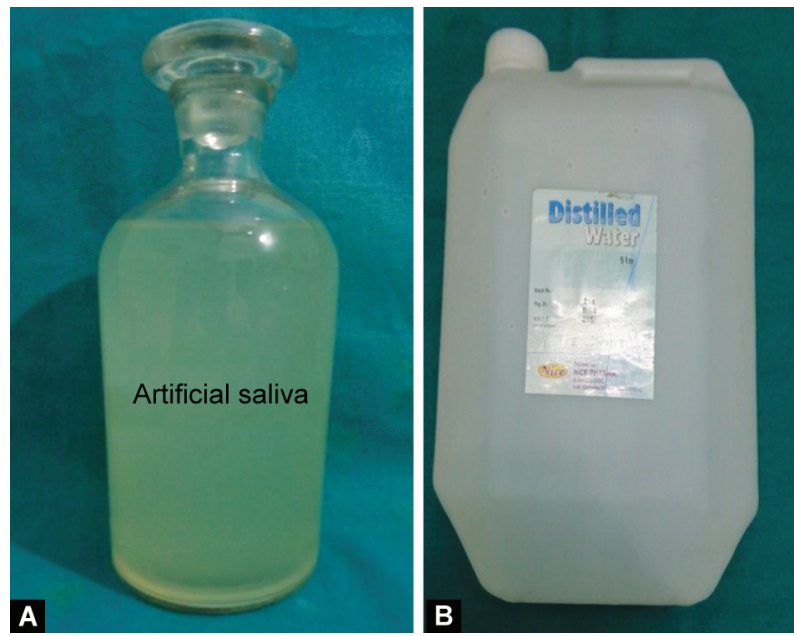

Figs 1 A and B: Materials used in the study: (A) Artificial saliva; (B) Distilled water
Group I-30 samples were immersed in chocolate milk (Amul Kool Koko).

Group II-30 samples were immersed in sweet lassi (verka).

Group III-30 samples were immersed in soya milk chocolate (sofit).

Each group was further subdivided into 2 subgroups of 15 samples each based on the number of immersion cycles per day:

Subgroup la, Ila, Illa: samples were completely immersed in their respective beverages and subjected to one immersion/day in $25 \mathrm{~mL}$, of the beverage for 5 minutes. This process was repeated daily for 7 days at the same time.

Subgroup Ib, Ilb, Illb: samples were completely immersed in their respective beverages and subjected to three immersions/day in $25 \mathrm{~mL}$, of the beverage for 5 minutes. Immersions were evenly distributed over 12 hours, i.e., after every 4 hours. The process was repeated daily for 7 days at the same time.

After each immersion, the samples were rinsed with distilled water and were placed in artificial saliva (Fig. 3). Once the immersion cycles were complete, wax from each sample was removed with a gentle stream of warm water using a syringe and 20-gauge needle and each sample was blot dried.

After completion of immersion cycles, the surface roughness was evaluated for both the exposed as well as an unexposed portion of the sample using a surface profilometer (Fig. 4), and the surface microhardness was tested using a Vickers Microhardness tester (Fig. 5). Data obtained were put to statistical analysis. Mean and standard deviation for surface roughness and microhardness values were obtained for all the subgroups by using paired " $t$ " test and post hoc test.

The results of the study are as follows (Tables 1 to 4) (Fig. 6).
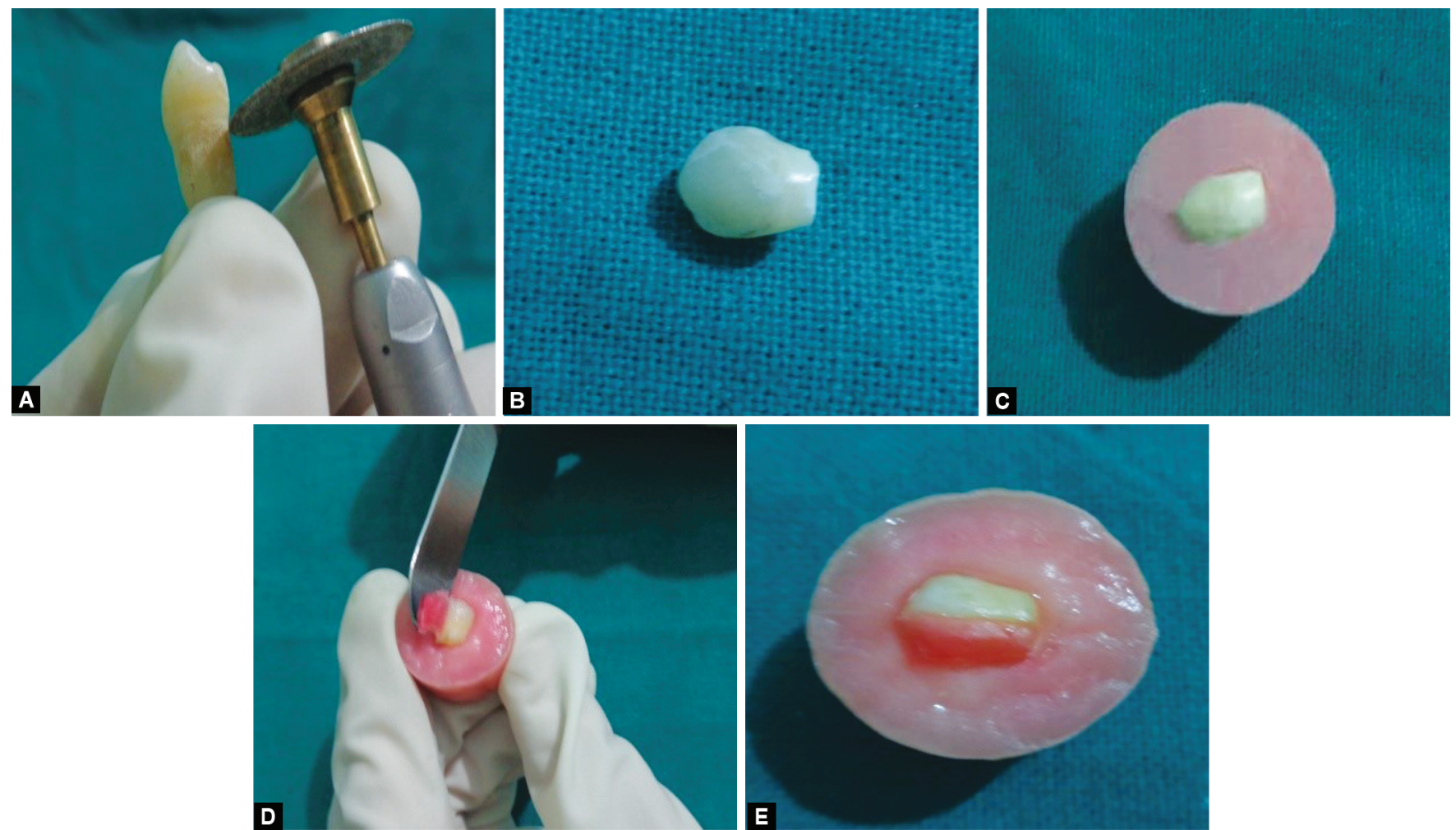

Figs 2A to E: (A) Sectioning of tooth from cementoenamel junction; (B) Coronal section obtained after sectioning; (C) Embedding the section in acrylic block; (D) Waxing up of sample to differentiate between exposed and unexposed surface; (E) Prepared sample 

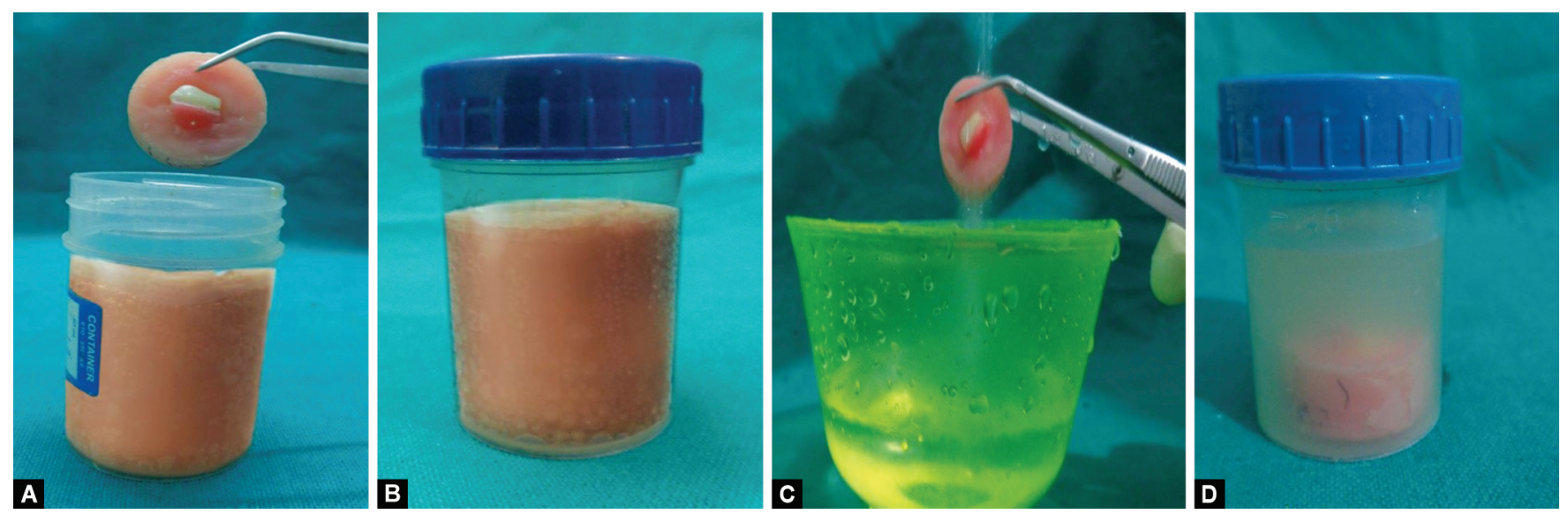

Figs 3A to D: (A) Immersion of sample in beverage; (B) Sample fully immersed in beverage; (C) Rinsing the sample with distilled water; (D) Storage in artificial saliva

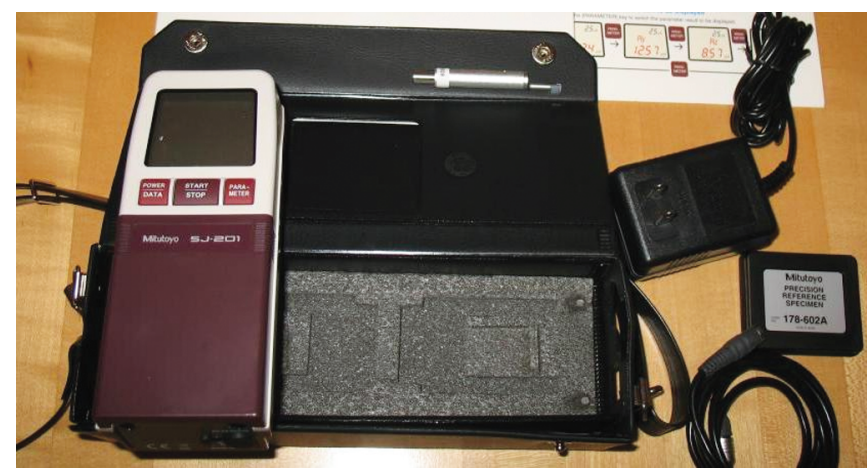

Fig. 4: Profilometer

Table 1: The mean surface roughness values $(\mathrm{Ra}, \mu \mathrm{m})$ of waxed/ unexposed (control) and unwaxed/exposed (experimental) surfaces of human enamel of groups I, II, and III following different immersion regimes

\begin{tabular}{|c|c|c|c|c|}
\hline Group & $\begin{array}{l}\text { No. of } \\
\text { samples }\end{array}$ & Subgroup & $\begin{array}{l}\text { Mean sur- } \\
\text { face rough- } \\
\text { ness of an } \\
\text { unexposed } \\
\text { surface of } \\
\text { the enamel }\end{array}$ & $\begin{array}{l}\text { Mean } \\
\text { surface } \\
\text { roughness ol } \\
\text { an exposed } \\
\text { surface of } \\
\text { the enamel }\end{array}$ \\
\hline \multirow{2}{*}{$\begin{array}{l}\text { Group I } \\
\text { chocolate } \\
\text { milk (amul } \\
\text { kool koko) }\end{array}$} & 15 & $\begin{array}{l}\text { la ( } 1 \text { immersion } \\
\text { per day) }\end{array}$ & $0.38 \pm 0.21$ & $0.16 \pm 0.14$ \\
\hline & 15 & $\begin{array}{l}\text { Ib ( } 3 \text { immersions } \\
\text { per day) }\end{array}$ & $0.38 \pm 0.22$ & $0.10 \pm 0.10$ \\
\hline \multirow{2}{*}{$\begin{array}{l}\text { Group II } \\
\text { sweet lassi } \\
\text { (verka) }\end{array}$} & 15 & $\begin{array}{l}\text { Ila ( } 1 \text { immersion } \\
\text { per day) }\end{array}$ & $0.23 \pm 0.13$ & $0.52 \pm 0.28$ \\
\hline & 15 & $\begin{array}{l}\text { Ilb ( } 3 \text { immersions } \\
\text { per day) }\end{array}$ & $0.23 \pm 0.13$ & $0.60 \pm 0.35$ \\
\hline \multirow{2}{*}{$\begin{array}{l}\text { Group III } \\
\text { soya milk } \\
\text { chocolate } \\
\text { (sofit) }\end{array}$} & 15 & $\begin{array}{l}\text { Illa ( } 1 \text { immersion } \\
\text { per day) }\end{array}$ & $0.27 \pm 0.12$ & $0.11 \pm 0.10$ \\
\hline & 15 & $\begin{array}{l}\text { Illb } \\
\text { ( } 3 \text { immersions } \\
\text { per day) }\end{array}$ & $0.27 \pm 0.12$ & $0.11 \pm 0.21$ \\
\hline
\end{tabular}

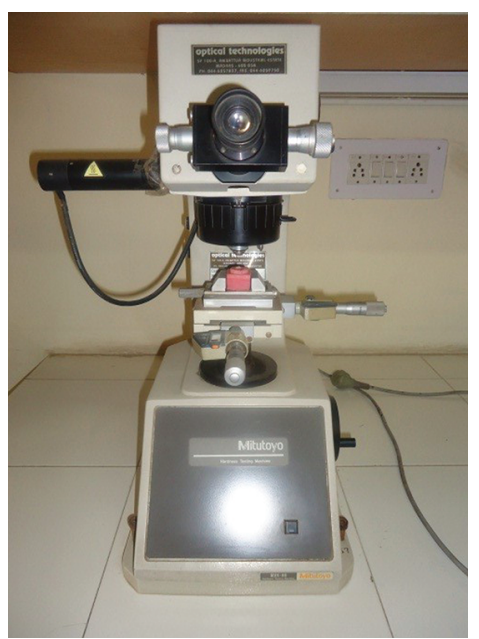

Fig. 5: Vickers microhardness tester

The results of the study showed that after immersion in these beverages the surface roughness and microhardness of the human enamel surface show a marked change. Among chocolate milk, lassi, and soya milk, a decrease in the surface roughness of enamel was noted with chocolate milk and soya milk. Also, an increase in the surface roughness of enamel was noted with lassi.

On comparing the microhardness of enamel with and without exposure to these beverages, an increase was noted in all groups with a maximum increase shown by chocolate milk followed by soya milk and sweet lassi.

It was observed that the effect of a beverage become more accentuated as the number of immersions increased from 1 to 3 immersions.

\section{Discussion}

The results can be explained as follows:

The effect of a beverage on enamel can only be assessed by knowing the chemical composition of these beverages. Milk is a complex colloidal mixture of proteins, minerals, fat, lactose, and other constituents. Soymilk is an extract of soybean and consists of proteins and minerals. Lassi is obtained from the fermentation of milk and it contains an almost equal amount of proteins and minerals as that of milk. The result of the chemical assay of the 
Table 2: The mean surface microhardness values (HV) of waxed/unexposed (control) and unwaxed/exposed (experimental) surfaces of human enamel of groups I, II, and III following different immersion regimes

\begin{tabular}{lllll}
\hline Group & $\begin{array}{l}\text { No. of } \\
\text { samples }\end{array}$ & Subgroup & $\begin{array}{l}\text { Mean microhardness of } \\
\text { unexposed enamel surface }\end{array}$ & $\begin{array}{l}\text { Mean microhardness of } \\
\text { exposed enamel surface }\end{array}$ \\
\hline Group I chocolate milk (amul kool koko) & 15 & la (1 immersion per day) & $343.20 \pm 32.07$ & $364.73 \pm 31.91$ \\
& 15 & Ib (3 immersions per day) & $358.47 \pm 32.62$ & $465.13 \pm 16.04$ \\
Group II sweet lassi (verka) & 15 & Ila (1 immersion per day) & $350.47 \pm 28.69$ & $356.07 \pm 31.46$ \\
& 15 & Ilb (3 immersions per day) & $341.53 \pm 36.37$ & $359.00 \pm 40.38$ \\
Group III soya milk chocolate (sofit) & 15 & IIla (1 immersion per day) & $349.93 \pm 30.95$ & $361.80 \pm 32.23$ \\
& 15 & IIlb (3 immersions per day) & $340.13 \pm 26.23$ & $400.93 \pm 25.31$ \\
\hline
\end{tabular}

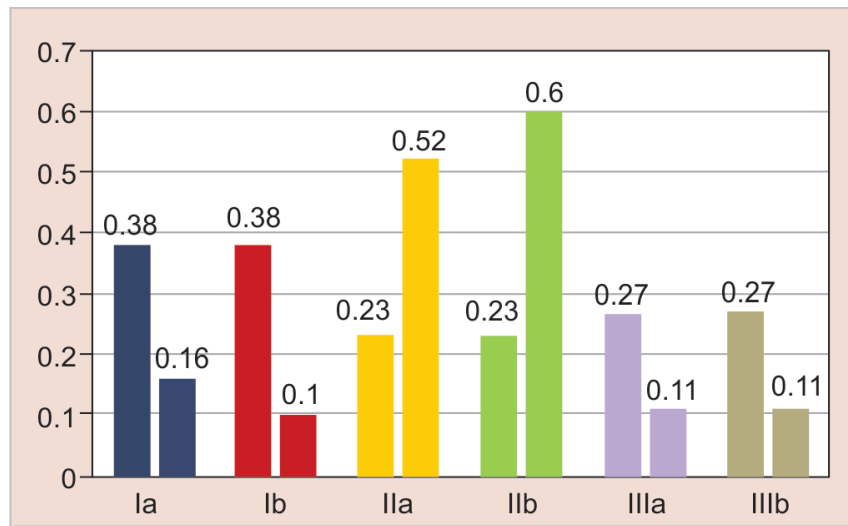

First bar of each group: Mean surface roughness of unexposed/waxed surface Second bar of each group: Mean surface roughness of exposed/unwaxed surface A

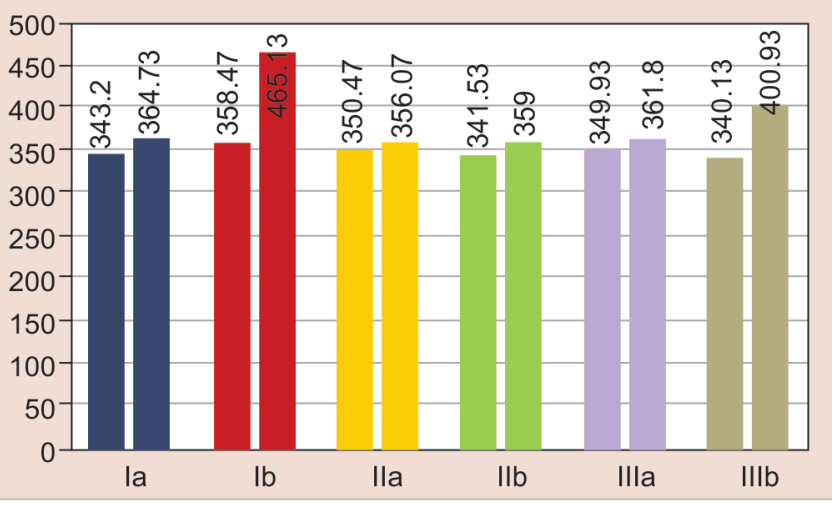

First bar of each group: Mean surface roughness of unexposed/waxed surface Second bar of each group: Mean surface roughness of exposed/unwaxed surface B

Figs $6 \mathrm{~A}$ and B: Graphs representing the surface roughness and microhardness of human enamel before and after immersion in milk-based beverages

Table 3: Comparison of difference of the mean surface roughness values ( $\mathrm{Ra}, \mu \mathrm{m})$ of waxed/unexposed (control) and unwaxed/exposed (experimental) surfaces of the enamel of groups I, II, and III following different immersion regimes

\begin{tabular}{|c|c|c|c|c|c|}
\hline Group & Subgroup & $\begin{array}{l}\text { Difference between } \\
\text { the mean of surface } \\
\text { roughness of unex- } \\
\text { posed and exposed } \\
\text { enamel surfaces }\end{array}$ & $\begin{array}{l}\text { Standard deviation } \\
\text { of the difference of } \\
\text { the mean of surface } \\
\text { roughness of unex- } \\
\text { posed and exposed } \\
\text { enamel surfaces }\end{array}$ & tvalue & Significance \\
\hline \multirow[t]{2}{*}{ Group I } & la & 0.22 & 0.18 & 4.70 & $<0.001(\mathrm{HS})$ \\
\hline & $\mathrm{Ilb}$ & 0.28 & 0.21 & 5.20 & $<0.001(\mathrm{HS})$ \\
\hline \multirow[t]{2}{*}{ Group II } & Ila & -0.28 & 0.27 & -3.97 & 0.002 (NS) \\
\hline & $\mathrm{Ilb}$ & -0.36 & 0.32 & -4.30 & $0.001(\mathrm{~S})$ \\
\hline \multirow[t]{2}{*}{ Group III } & Illa & 0.15 & 0.09 & 6.52 & $<0.001(\mathrm{HS})$ \\
\hline & IIIb & 0.16 & 0.24 & 2.60 & $0.021(\mathrm{NS})$ \\
\hline
\end{tabular}

Table 4: Comparison of the difference of the mean microhardness values (HV) of waxed/unexposed (control) and unwaxed/exposed (experimental) surfaces of the enamel of groups I, II, and III following different immersion regimes

\begin{tabular}{llllrl}
\hline \multicolumn{7}{c}{} & $\begin{array}{l}\text { Difference between the mean of } \\
\text { microhardness of unexposed and } \\
\text { Group }\end{array}$ & Subgroup & $\begin{array}{l}\text { Standard deviation of the difference of the } \\
\text { mean of microhardness of unexposed and } \\
\text { exposed enamel surfaces }\end{array}$ & t value & Significance \\
\hline Group I & la & -21.53 & 14.83 & -5.62 & $<0.001$ (HS) \\
& IIb & -106.67 & 26.98 & -15.32 & $<0.001$ (HS) \\
Group II & II & -8.60 & 30.16 & -1.10 & $>0.001$ (NS) \\
& IIb & -14.47 & 24.59 & -2.28 & $>0.001$ (NS) \\
Group III & IIla & -21.87 & 17.00 & -4.98 & $<0.001$ (HS) \\
& IIIb & -60.80 & 32.11 & -7.34 & $<0.001$ (HS) \\
\hline
\end{tabular}


Table 5: The number of various ions and parameters in the beverages used in the study

\begin{tabular}{lllll}
\hline & & Chocolate & & Soya \\
S. no. & Name of the parameter & milk & Lassi & milk \\
\hline 01 & $\mathrm{pH}$ & 7.2 & 5.5 & 6.8 \\
02 & Release of $\mathrm{H}^{+}$ions & No & Yes & No \\
03 & Calcium ions $(\mathrm{g} / 100 \mathrm{~mL})$ & 160 & 122 & 248 \\
04 & Phosphate ions $(\mathrm{g} / 100 \mathrm{~mL})$ & 125 & 91 & 101 \\
05 & Protein $(\mathrm{g} / 100 \mathrm{~mL})$ & 3.8 & 2.43 & 6.7 \\
\hline
\end{tabular}

beverages used in the study reveals the difference in the following parameters of these beverages (Table 5):

- $\mathrm{pH}$

- Calcium concentration

- Phosphate concentration

- Protein content.

These parameters create an environment leading to a series of cycles of loss and gain of the mineral content of the surface layer in the beverages. The final outcome is the result of these cycles of gain and loss of minerals. In the factors noted above, the $\mathrm{pH}$ governs the loss of minerals, i.e., calcium and phosphate of the enamel. However, calcium and phosphate content prevents the loss of the minerals since they tend to create a supersaturated solution of minerals around the enamel surface leading to no further leaching of the minerals out of the enamel surface. Since lassi is slightly acidic in nature and has the least concentration of calcium, phosphate, and protein in the chemical analysis, it shifts the balance toward the loss of minerals from the surface. The greatest decrease in surface microhardness and maximum increase in surface roughness of enamel by immersion in lassi explains the results.

However, when the mechanical parameters of milk are compared with soy milk, it is noted that though it has been fortified with calcium still the effects seen by soya milk are less pronounced as compared to milk. This can be explained by the presence of organic proteins in milk. According to Oliveira et al., ${ }^{7}$ the beneficial effect of milk is not only related to a large amount of calcium and phosphates in the composition of milk but also because it has some phosphoproteins, such as casein. ${ }^{8}$ The role of casein in demineralization was hypothesized by Bamise et al. ${ }^{9}$ and Attin et al. ${ }^{10}$ According to him, casein can bind to the hydroxyapatite surface and stay there as a thin layer, which acts as a dissolution barrier, restricting the $\mathrm{H}^{+}$access to the crystal surface and preventing diffusion of ions away from hydroxyapatite. Another alternative theory also proposed by these authors says that casein molecules may bind to sites of high energy on the crystal surface, thus preventing ion detachment from these sites. ${ }^{11-13}$

However, there are several buffer mechanisms active in the oral cavity which might have a different effect on the interactions of these beverages intraorally. Thus, further clinical studies are required to simulate biological conditions and assess the effects of these health drinks on the human enamel surface.

\section{Conclusion}

The results can hence be concluded as follows:

In relation to microhardness values obtained:

Chocolate milk (Amul Kool Koko) > soya milk chocolate (sofit) $>$ sweet lassi (verka) > control.
In relation to surface roughness values obtained:

Sweet lassi (verka) > control > soya milk chocolate (sofit) > chocolate milk (Amul Kool Koko).

Also, the effect of beverages pronounced as the number of exposure increases.

\section{Clinical Significance}

Therefore, the present study states that though the consumption of these beverages has been increasing, the effects of these beverages on the tooth cannot be neglected. We, as parents and pediatric dentists, should be aware of the effects of beverages on enamel considered to be health drinks. Such awareness is essential in formulating a non-erosive, non-cariogenic diet plan for the child especially during the periods of the window of infectivity to prevent caries and erosion risks.

\section{References}

1. Vongsavan K, Surarit R, Rirattanapong P. The effect of high calcium milk and casein phosphopeptide-amorphous calcium phosphate on enamel erosion caused by cholinated water. Southeast Asian J Trop Med Public Health 2010;41(6):1494-1499.

2. Dhanker K, Ingle NA, Kaur N. Effect of commercial and domestic beverages on calcium release from enamel surfaces. J Adv Oral Research 2013;4(2):6-10. DOI: 10.1177/2229411220130202.

3. Haghgoo R, Mehran M, Baghaiipour SA. In-vitro evaluation of the effect of addition of xylitol to carbonated diet soda on enamel microhardness of permanent teeth. J Islamic Dent Assoc Iran (JIDA) 2013;25(2):147-151.

4. Von fraunhofer JA, Rogers MM. Dissolution of dental enamel in soft drinks. Gen Dent 2004;52(4):308-312.

5. Poggio C, Lombardini M, Dagna A, et al. Protective effect on enamel demineralization of a CPP-ACP paste: an AFM in vitro study. J Dent 2009;37(12):949-954. DOI: 10.1016/j.jdent.2009.07.011.

6. Maupome G, Matsuya $Y$, Yamamoto $Y$, et al. In vitro quantitaive assessment of enaeml microhardness after exposure to eroding immersion on a cola drink. Caries Res 1988;32(2):148-153. DOI: 10.1159/000016445.

7. Oliveira TAD, Scaramucci T, Braga RGM, et al. The effect of milk ingestion after an orange juice in the superficial microhardness of human enamel: an in vitro study. Rev Pós Grad 2012;19(3):89-94.

8. Bamise CT, Ogunbodede EO, Olusile AO, et al. Erosive potential of soft drinks in Nigeria. World J Med Sci 2007;2(2):115-119.

9. Bamise CT, Kolawol KA, Oloyede EO. The determinants and control of soft drinks-incited dental erosion. Rev Clin Pesq Odontol 2009;5(2):141-154.

10. Attin T, Weiss K, Becker $K$, et al. Impact of modified acidic soft drinks on enamel erosion. Oral Dis 2005;11(1):7-12. DOI: 10.1111/j.16010825.2004.01056.x.

11. Fahad AH, Al-Weheb AM. Effect of casein phosphopeptideamorphous calcium phosphate on the microhardness and microscopic features of the sound enamel and initial caries-like lesion of permanent teeth, compared to fluoridated agents. J Bagh College Dentist 2012;24(4):114-120.

12. Grewal N, Kudupudi V, Grewal S. Surface remineralization potential of casein phosphopeptide-amorphous calcium phosphate on enamel eroded by cola-drinks: An in-situ model study. Contem Clin Dent 2013;4(3):331-333. DOI: 10.4103/0976-237X. 118385.

13. Kargul K, Caglar E, Tanboga I, et al. A new model: in vitro erosion of minipig enamel cased bz fruit yogurt. OHDMBSC 2003;2(4): 8-12. 